\title{
Seeking the Golden Thread
}

\section{Michael Harris Bond}

Beyond the Chinese Face: Insights

From Psychology

London: Oxford University Press,

1991. 125 pp. ISBN 0-19-585116-1.

$\$ 16.95$ paperback

\begin{abstract}
Michael Harris Bond, professor of psychology at the Chinese University of Hong Kong (Shatin), is editor of The Psychology of the Chinese People and of The Cross-Cultural Challenge to Social Psychology. $\square$ Robert V. Levine, chair and professor of psychology at California State University (Fresno), is author of the chapter "The Pace of Life Across Cultures" in J. McGrath (Ed.) The Social Psychology of Time: New Perspectives.
\end{abstract}

$\mathrm{T}$ he bulk of cross-cultural research in psychology has been conducted, as Michael Bond puts it, "safari style" (p. 33) - by Westerners on sabbatical leave. One notable exception is the work of Bond himself. Having spent more than 16 years in Hong Kong, he has lived the Chinese experience. To our good fortune, Bond is also one of the premier thinkers in the field of cross-cultural psychology. In this slender treatise on the Chinese character, he combines his Asian background with his expertise in psychology, and the result is a polished gem.

The book is intended as a layperson's version of The Psychology of the Chinese People, edited by Bond (1986), which is arguably the premier academic book on the topic. The current book meets its new audience with ease and intelligence. It is the sort of book that George Albee no doubt had in mind when he challenged psychology to give itself away.

It also goes beyond its longer and more technical predecessor in some ways. In the current book, Bond worked to identify the "golden thread" that ties together the qualities that make the Chinese unique - an integration of material that the earlier book lacked. Fitting together the data from each of the idiosyncratic research programs in this area is, of course, ultimately an impossible task. But Bond comes closer to success than his many predecessors.

Despite its brevity, the book covers a wide range of material. Bond moves in logical succession from chapters on the socialization of the Chinese child, to cognitive styles, personality characteristics, social behavior, and on to organizational behavior. There are also sections on psychopathology and the effects of modernization on the loss of "Chineseness."

\author{
Review by \\ Robert V. Levine
}

Some of the sections are, perhaps, a bit more technical than one would expect in a book for the layperson. An early chapter dealing with the socialization of the Chinese child is an example of this. But Bond uses much of this material to lay the foundation for many of the more provocative ideas in later chapters.

Like most valuable cross-cultural psychology, some of the best material in this book teaches as much about the arbitrariness, narrowness, and ethnocentricity of the reader's own cultural values as they do about Chinese culture itself. A chapter on social harmony, for example, sketches the importance that Chinese people place on social harmony. Bond demonstrates how the "internal characteristics" (p. 48) of the Chinese, which he had described in the previous chapter, often take on less importance than they do in the West. A defining characteristic of this collectivist culture, Bond explains, is the attention that people pay to the targets of their behavior and the context of the interaction. Although the focus here is always on Chinese eollectivism, the chapter ultimately serves as a valuable reading about the boundaries and limitations of Western individualism.

A book of this kind is always subject to the criticism that it overgeneralizes and stereotypes the group under study. Bond does tend to generalize about the Chinese character-this is, in fact, one of the goals of the book-but always with sensitivity and intelligence. He is not only aware of the dangers of oversimplifying the characteristics of a group of people but faces the problem head-on in his opening chapter, titled "Some Warnings about Studying the Chinese Scientifically."

Beyond the dangers of stereotyping, however, Bond recognizes the enormous value of identifying and understanding the characteristics that distinguish one group of people from another. The biologist Lewis Thomas, when describing the organisms of our planet, once said that "there is nothing unique about being unique" ("Notes of a Biology Watcher," 1982). It is by exploring each of our unique differences that people ultimately come to understand and accept one another. Bond's generalizations about the Chinese are always framed in this context of cross-cultural discovery. More important, perhaps, his generalizations are data-based and scientifically scrutinized, which is not the case for many other books about the Chinese (or most other) people.

Bond is a master of the metaphor, and he treats us with vivid imagery in his writing throughout the book. He also sprinkles the text with captivating Chinese (and others') sayings (e.g., the book begins with the Chinese adage, "The eye cannot see its own lashes" (p. 1]).

Bond concludes with an Afterword, in which he seeks to identify the thread that ties together the characteristics that make the Chinese unique. Is there a unique Chineseness? Has Bond revealed the golden thread? To both questions, the author would be the first to offer an "Oriental yes and no" (p. 118). What is unambiguous, however, is that he brings more light to these questions than has any psychologist before him.

Can Bond pull all of this off in 125 pages? Again, the answer is yes and no. On the one hand, there were a number of instances where I wished he had pushed further. In the chapter on psychopathology, for example, he whets the appetite with intriguing facts about the gambling compulsion that characterizes many Chinese people (e.g., per capita, Hong Kong residents bet more at the race track in 1989 than people from China earned) but quickly moves away to more general issues. On the other hand, Bond manages to pack so much information into this compact book, with such a readable cadence and vivid style, that its size often seems just right.

The book begins with an anecdote about a Chinese colleague who remarked to Bond that there are "hundreds of books like yours, purporting to explain the Chinese." Quickly, the man then adds, "Of course yours will be better" (p. 1). Bond attributes this praise to the man's Chineseness. Well, I am a fully westernized Anglo-American, with no such cultural constraints. But, I com- 
pletely agree with the man: This book is better.

\section{References}

Bond, M. H. (Ed.). (1986). The psychology of the Chinese people. London: Oxford University Press.
WGBH Boston, \& BBC London

(Producers). (1982). “Notes of a biology watcher." In Nova. Public Broadcasting Service.

\section{Understanding the Self}

\author{
Don Hamachek \\ Encounters With the Self (4th ed.) \\ San Diego, CA: Harcourt Brace \\ Jovanovich, 1992. 382 pp. \\ ISBN 0-03-055744-5. \$22.00 \\ paperback
}

Don Hamachek, professor of counseling and educational psychology at Michigan State University (East Lansing), is author of Psychology in Teaching, Learning, and Growth (4th ed.); editor of Educational Psychology Reader: Toward the Improvement of Schooling; and author of the chapter "Changes in the Self From a Developmental/Psychosocial Perspective" in the forthcoming T. M. Brinthaupt and R. P. Lipka (Eds.) Changing the Self: Philosophies, Techniques, and Experiences. Mark R. Leary, professor of psychology at Wake Forest University (Winston-Salem, North Carolina), is author of Understanding Social Anxiety and Introduction to Behavioral Research Methods and coauthor, with R. S. Miller, of Social Psychology and Dysfunctional Behavior.

$\mathrm{T}$ he concept of the self has had an uneven history in psychology. Early writers such as James, Cooley, and Mead gave the study of the self a good start in the formative days of behavioral science, only to have researchers virtually banish the concept during the heyday of behaviorism. For many years, the self's primary haven was in the shelters provided by humanistic and existential psychologists. Since the early 1970s, however, the self has reemerged from exile and played an increasingly prominant role in theory and research, leading Baumeister (1987) to observe that "the self must be ranked with dissonance and attributions as one of the fundamental issues that has concerned social and personality psychologists" (p. 163).

The fourth edition of Hamachek's Encounters With the Self, first published in 1971 , provides an integrative and farranging overview of the research on the self. Its purview is unusually (but appropriately) broad; it draws on work in personality, social, developmental, clinical, counseling, school, and educational psychology: The first three chapters address basic issues regarding the development of the self, the fundamental motives of self-esteem protection and self-consistency, and the effects of the self on peo- ple's perceptions of themselves and others. Chapters 4 through 6 focus primarily on factors that affect the self-concept and the consequences of one's self-concept voted to the effects of appearance, family relationships, and academic factors. The final chapter discusses factors that facilitate and impede the development of a positive self-concept.

Although the theme of the self runs throughout the book, the text meanders at several points to discussions of more general processes in personality, social, and developmental psychology, such as the question of behavioral consistency, the use of trait and type theories, the effects of physical attractiveness on behavior, and the factors that influence parental style. These digressions complement the material on the self nicely, but they sometimes stray too far from the central theme of the book.

Hamachek is an uncommonly good writer, easily accomplishing his stated goal to present the content "in a manner that could be understood by readers who come to it from a variety of backgrounds" (p. vi). The presentation is well organized and coherent, and the author does a good job of integrating recent research with the material from previous editions. To for behavior; individual chapters are de- enhance the personal relevance of the material for the reader, Hamachek effectively sprinkles case studies and examples throughout the book and encourages the reader to consider the material in light of his or her own experiences. The coverage and style make Encounters With the Self equally appropriate for courses in introductory psychology; advanced courses in developmental, personality, social, or school psychology; and graduate-level offerings.

My primary disappointment was that many of the most exciting advances in self-research during the past decade did not find their way into the book, and many of the researchers who have contributed most notably to the recent surge of interest in the self are absent. Topics that are conspicuous by their absence include self-awareness theory, self-efficacy theory, self-evaluation maintenance theory, self-discrepancy theory, the ante2 cedents and effects of self-attributions, public and private self-consciousness, social identity theory, and self-verification processes, as well as a great deal of the recent research on self-esteem maintenance, Despite a few holes in its coverage of the self literature, Encounters With the Self is an interesting, wellwritten book that would serve as a useful text in a variety of courses.

\section{Reference}

Baumeister, R. F. (1987). How the self became a problem. Journal of Personality and Social Psychology, 52, 163-176. 